\title{
The Comparison of Sino-US Financial Undergraduate curriculum and The Inspiration to China's Finance Education
}

\author{
Chen, Xiuhua \\ Finance College , Shandong University of Finance and Economics \\ Jinan, China \\ E-mail:0531j@sina.com
}

\begin{abstract}
Comparing to the development of finance in the United States, China's finance curriculum and teaching philosophy is obviously lagging behind. This article identified the differences of finance Curriculum between China's and American Universities, deeply analysed the main problems in the finance undergraduate teaching of China's colleges and universities. It will be helpful to enhance the teaching level of finance courses, constantly improve the teaching contents and cultivate financial professionals that meet the social needs .
\end{abstract}

Key words-Finance undergraduate education; Curriculum; Sino-US comparison

\section{I . INTRODUCTION}

Since the beginning of the twenty-first century, finance has become the most popular subjects in modern economics. The traditional finance undergraduate education in China, however, is facing increasingly serious challenges, which reflected in the contradiction between supply and demand of human capital market in the financial industry. One of the important reasons that caused a serious gap between talent supply and demand of China's financial industry is that finance curriculum exists backward, chaotic and many other issues. In contrast, as the most developed country in financial system, the United States has reached an advanced level in finance undergraduate education. Therefore, we tried to find the the differences of finance Curriculum between China's and American Universities by the Sino-US comparision, in order to give some inspiration to our finance undergraduate education , to rebuild financial curriculum system combined with the actual situation in China and to reform and improve our finance teaching content at a higher starting point.

\section{FINANCE UNDERGRADUATE CURRICULUM IN CHINA AND THE UNITED STATES}

In generally, finance undergraduate courses in American Universities includes liberal arts courses, core courses, finance major courses and elective courses. The most significant feature of undergraduate education in the United States is liberal arts education which promote students' ability to adapt to a variety of job. The credits of liberal arts courses typically account for $13 \%-16 \%$ of the total credits. It is until the second year in university can the students determine their major and the major courses does not exceed $1 / 3$ of the total courses. While Chinese student determine their major when they enrollment and their major is determined according to the college entrance examination scores, rather than according to their interests of the students. In the U.S. ,before learning major core course, the students must learn public core courses to ensure that students have mastered the full theoretical basis and the basic analytical skills and tools such as statistics, accounting etc., the public core courses usually include macro and micro economics, statistics, accounting, finance principles etc. The major core curriculum is not exactly the same in different university, but they both mainly focus on money and banking, corporate finance, investment principles, the international monetary and finance, financial institutions etc. Some colleges and universities offer a large number of unique, practical courses according to their specialty in teaching and research and the need of financial industry. For example, MIT offers case course in financial management; the Wharton School of the University of Pennsylvania offers many unique cousres such as mutual fund investment, venture capital and financial innovation courses aimed to investment fields and the course on mergers, acquisitions and restructuring aimed to enterprise capital operation issues; corporate finance, financial seminar , real estate finance, futures and options markets, entrepreneurs finance, financial derivatives, behavioral finance, fixed income securities, international banking, financial markets and others are often selected. Specific curriculum are shown in Table 1.

In chinese colleges and universities, finance curriculum is composed mainly by the public required courses, major fundamental courses, major core courses and electives courses. public required courses includes cultivation of ideological morality, fundamentals of law, political theory course, physical education, English, calculus and computer course. Major fundamental courses usually include economics, accounting, management , statistics, international trade, money and banking. Major core courses include financial market, international finance, central Banking, insurance and public finance. The majority colleges have no right to choose theses courses by themselves because they have to meet the requirements of the Ministry of Education on undergrauate fundanental courses and major core courses. The elective courses usually include operation and management of commercial banks, the theory and practice of investment banking, securities investment, financial institutions, risk management, financial derivatives, fixed income securities, 
financial engineering, international settlement, financial regulatory theory, foreign banking system and financial English, personal finance,compare the financial system, financial topics, international Economics which cover almost all the main branches of financial fields.

Table 1 Finance curriculum in the U.S

\begin{tabular}{|l|l|}
\hline $\begin{array}{l}\text { Major } \\
\text { required } \\
\text { courses }\end{array}$ & $\begin{array}{l}\text { Foundations of Financial Markets, Corporate Finance, } \\
\text { Financial Institutions , International Financial } \\
\text { Management, Monetary Economics }\end{array}$ \\
\hline \multirow{5}{*}{$\begin{array}{l}\text { Risk Management In Financial Institutions, Topics in } \\
\text { Emerging Financial Markets, Debt Instruments and } \\
\text { Markets, Behavioral Finance, Real Estate Capital } \\
\text { Markets, Real Estate Finance, Equity Valuation , } \\
\text { Microfinance , Futures and Options, Investment } \\
\text { Banking, Corporate Mergers \& Acquisitions, Topics in } \\
\text { Entrepreneurial Finance , Independent Study in } \\
\text { Finance Introduction to Empirical Methods in } \\
\text { Finance, Topics In Asset Pricing, Selected Topics in } \\
\text { Empirical Corporate Finance, Monetary Economics and } \\
\text { the Global Economy, Investment Management , } \\
\text { Financial Derivatives, , International Banking, Fixed } \\
\text { Income Securities. Capital Markets - Formerly Funding } \\
\text { Investments, Behavioral Finance, Venture Capital and } \\
\text { the Finance of Innovation, The Finance of Buyouts and } \\
\text { Acquisitions. }\end{array}$} \\
\hline
\end{tabular}

From a general point of view, China has established a relatively rich and scientific finance curriculum system, but there are still a tendency that attach importance to theory but contempt application, attach importance to teaching knowledge but contempt ability and quality training. By comparing the differences between China and the United States on the curriculum of finance higher education , it reflects differences in training objectives, teaching content, teaching methods etc., we should learn from each other,so that we can constantly supplement, amend and improve China's finance teaching content.

\section{THE COMPARISON OF SINO-US FINANCIAL UNDERGRADUATE CURRICULUM}

\section{A. the differences on education objectives}

From the analysis on the finance major in the United States, we can see that the finance graduates training objectives of the American Universities focus on practicality. The United States is a very practical-oriented country, and this is also reflected in the finance personnel training. In addition, the American universities' major setting are partly followed this market principles. If you do not have enough students to apply for a major, this major can easily be canceled which form an external constraint on the curriculum. Practicality is the most emphasized training objectives of the finance major in most American universities. While for a long time, our universities' undergraduate training objective of finance major are targeted at the "senior specialists" in various finance-related positions, which is an unrealistic training goal. The consequences resulted from this unrealistic objective is that a large proportion of the finance graduate student is difficult to find a job. The society and even the students themselves are no longer considered the the undergraduate major in finance is the so-called "senior specialists". So, for the vast majority of Chinese colleges and universities with a finance undergraduate, practicality should become an most important guiding ideology of finance undergraduate training.

\section{B. The differences in teaching philosophy and teaching methods}

Corresponding with the training objectives, there are considerable differences in the teachers' teaching philosophy and teaching methods between China and the United States, and these differences directly result in the huge differences of the students on the learning method and application capabilities.

In the colleges and universities of the United States, teachers speak less and students do more. The teachers are not only to impart knowledge, but they also emphasis on the cultivation of students' self-learning ability, innovation ability and teamwork cooperation ability. Because there are many courses, the curriculum is arranged densely. Due to the limited class hour and the great knowledge of each course, sometimes the teachers just impart knowledge to students in class, students need to spend a lot of time to digest the lesson after class, and usually need to read a lot of extracurricular information.

In the majority of colleges and universities of China, the teachers are still using the traditional "spoon-feeding" teaching methods in personnel training and they do not attach importance to the cultivation of students' abilities and qualities. Chinese teachers have a strong sense of responsibility but lack of flexibility in teaching methods. There is a tacit understanding between teachers and students: the teachers will test what they taught in class and will not test what they did not teach in class. Teachers take full advantage of every minute to impart knowledge, fear missing anything, so they feel tired. Most students do not make any preparation before class, homework is all a matter of conscious and and is lack of teachers' supervision, so the teaching result is not ideal. In China, there are overlap and duplication between courses. For example, the efficient market theory of finance, it is learned both in the financial markets and investment principles, it is also mentioned in 
corporate finance. The course teaching hours is very long, so they will naturally repeat; and every course is staying in generally explain but lack of in-depth thinking through useing exercises and discussions.

\section{The differences between Macro- and micro-finance}

In U.S. , finance curriculum focused on reflecting the main content of the micro-finance. While In China, finance undergraduate curriculum is still showing strong macrofinance tendency, curriculum focus on central banking, money and banking, international finance, operation and management of commercial banks. Studying macrofinancial theory is of course important, you can understand and familiar with the operation of the financial system as a whole, it may be more useful for those students that will enter the People's Bank of China or macroeconomic management department after graduation. but, after all, there are few students can enter these sectors. For most students that will find a job in enterprise and a specific financial institutions, the curriculum is lack of practicality. What these microscopic departments need such as corporate finance, risk pricing, capital operation, the curriculum is set too less. Some colleges and universities with better conditions began to introduce original finance textbooks from the United States and try to update the teaching content and curriculum arrangement to a higher level, but because the professional teachers have not enough solid theoretical foundation and are restraint by the structure of knowledge, threr are lack of financial professionals that really in-depth study of microfinance and forefront of financial problems. At present some finance professionals also begun to focus on the forefront topics of finance such as the efficiency of financial markets, the pricing of financial assets, as well as risk and revenue, but there are less teachers that can firmly grasp the forefront theory of finance and can teach in depth such courses as financial markets, financial engineering,corporate finance etc.

D. The differences between the richness and novelty of course content

The public required courses in chinese universities always include Marxist political economy, Mao Zedong Thought, Deng Xiaoping Theory and "Three Represents" and the scientific concept of development, and military theory which is enduring and embodying Chinese characteristics. Comparing to the liberal arts education in U.S, the quality and quantity of our public required courses have a considerable distance to the requirements of higher education, because they failed to reach the goal of enhancing the students' cultural accomplishment. The excessive major core courses and the required courses seemed to be allencompassing, which caused a heavy burden on students. If taking into account our unique CET and NCRE, the pressure of the students is so overwhelming that personality development space is almost completely repressed and quality education become a castle in the air. Meanwhile, the quantity of elective courses is large, but the course content is static and update slowly, and timeliness is also poor.

\section{INSPIRATION TO CHINA'S FINANCE HIGHER EDUCATION}

Through the comparison of Sino-US financial undergraduate curriculum, we can get some inspiration on our finance higher education. We can combined china's reality with the advantages of the U.S, learn from each other, and constantly improve our teaching practice of finance higher education.

\section{A. the change of education objectives}

the guiding ideology of china's finance undergraduate education should be and must be made a major adjustment. We should abandon the objective of "training senior specialists" which is proved unrealistic and shift our focus to the students' overall quality of adapting to financial practices. We should clearly propose our undergraduate education objective is to "educate hands-on professionals to meet the needs of different levels of social organization, and lay the theoretical foundation for the higher stages of learning”. Our graduates should have a generous and solid economic and financial theory foundation and the ability to engage in specific financial operations, with a strong sense of the market economy and social adaptability.

\section{B. the construction of distinctive financial branch field}

In the United States each university has specialized finance program due to the different focus of each school's objective, and thus its curriculum may be different. The advantages of specialization are to make full use of teachers with different knowledge expertise, to train students according to their different background so that they can adapt to similar but different profession and have competitive advantage in a particular field. For China's universities with finance program, they should construct distinctive and focused financial branch field. Even the universities having strong strength in finance education, it is impossible to reach the domestic first-class status in every branch of financial field, but they must have one or several branches to be in the top . therefore, they should take their advantages and avoid disadvantages to select their fields to emphasis according to their history and current status of the finance education, especially the knowlegde background of the faculty.

\section{The construction of curriculum that combined macro-} finance with micro-finance

Modern financial theory has switched from macro to micro, being the asset selection and risk management of market and microeconomic entities as the core, which greatly improving the practicality of finance. Especially after entering the stage of financial engineering, the scientific and practicality of finance has been further enhanced. China's finance higher education should follow the micro trend of the mordern financial theory 
development and combined with china's reality to design curriculum that encompassing the content of both macrofinance and micro-finance. Macro-finance and micro-finance should collaboratively develop. China's Economic system reform target mode determines that macro-control is indispensable, so macro-financial content , such as monetary policy and the central bank etc., must be take a seat, but at the same time we need to increase the content of micro-finance in practical courses. In a word, our overall though on finance curriculum is to take account into both macro and micro and to complement micro-finance in practical courses.

D. Reform of teaching methods by increasing the proportion of the case study and simulation teaching

China should learn from the experience of American Universities, and increase the proportion of case teaching and simulation teaching in major courses to improve teaching effectiveness. The traditional view is that the finance and other liberal arts majors do not require the use of laboratory simulation teaching, the development of the financial practice, however, made simulation teaching step into the classroom of our college and universities. Primary simulation teaching can be achieved through the establishment of a computer room, but a senior financial simulation teaching need to invest heavily in necessary teaching softwares and information receiving system that can receive financial and investment information, so that the simulation operation is much closer to the real operation of the financial markets practice. On the basis of simulation teaching being successfully carried out in demestic unversities, China should learn from the U.S. financial laboratory teaching experience in finance higher education, promote simulation teaching into a higher and wider application in finance education.

\section{REFERENCES}

[1] Zhao shan, "Build new finance higher education curriculum: based on Sino-US comparison”, Modern Education Science, 2008.09.

[2] She Derong, Ruan Mingfeng, Wang Li, "the Construction of the finance curriculum system of university," Chinese Adult Education, 2008.08.

[3] Gao Yan, "the plan and implementation on finance Undergraduate practice teaching in china's colleges and universities ," Technology Innovation Guide, 2008.08.

[4] Li Yinzhu, "Teaching method of college financial discipline”, Financial Education Research,2008.03.

[5] Pang Jinbo, Guo Xiangyu, Cui Ningbo, “ investigation on the training model innovation of finance undergraduate”, journal of Heilongjiang Province Administrative Cadre Institute of Politics and Law, 2009.06 